NJE Vol. 36: 54-63, 2020

Nigerian Journal of Entomology

Published by the Entomological Soc. of Nig.

www.esnjournal.com.ng

DOI.10.36108/NJE/0202/63.01.60

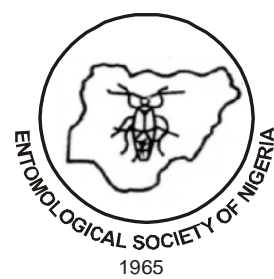

\title{
Bioefficacy of Extracts of Hyptis suaveolens, Eugenia aromatica and Azadirachta indica as Field Protectants of Pawpaw Against Paracoccus marginatus Will. and Granara de Willink in Ibadan, Southwest Nigeria
}

\author{
Okeke, ${ }^{*}$ S. A., ${ }^{1}$ Omoloye, A. A., ${ }^{1}$ Umeh, V. C. ${ }^{2}$ and Goergen, G. ${ }^{3}$ \\ ${ }^{1}$ Department of Crop Protection and Environmental Biology, University of Ibadan, Nigeria \\ ${ }^{2}$ National Horticultural Research Institute, Ibadan, Nigeria \\ ${ }^{3}$ International Institute of Tropical Agriculture, Cotonou, Benin
}

\begin{abstract}
The papaya mealybug, Paracoccus marginatus is a small sized polyphagous invasive hemipteran bug that attacks several genera of host plants, causing considerable yield loss. Commonly used insecticidal control is being discouraged due to environmental and human health hazards. Information on the control of this pest with botanicals is scanty, therefore the control using selected botanicals was investigated. Aqueous and ethanolic extracts of three botanicals: Hyptis suaveolens, Eugenia aromatica and Azadirachta indica were evaluated in screen cages $(1.80 \times 0.60 \times 1.50 \mathrm{~m})$ for contact toxicity following standard procedures. Cypermethrin ${ }^{\circledR}\left(100 \mathrm{ml}\right.$ a.i ha $\left.{ }^{-1}\right)$ was used as a standard check. The secondary metabolites in the three plants were analyzed for saponins, alkaloids, terpenoids, phenols, flavonoids and cardinolides following standard procedures. Effective concentration was determined using probit analysis. Both aqueous and ethanolic extracts of the botanicals caused adult mortality of $P$. marginatus. However, the difference in percentage mortality in aqueous extracts of $A$. indica (54.28 \pm 1.7$), H$. suaveolens $(47.5 \pm 4.1)$ and $E$. aromatica $(48.6 \pm 1.1)$ were not significant $(\mathrm{P}>0.05)$. Percentage mortality of ethanolic extracts of $A$. indica $(87.40 \pm 4.8)$ was significantly higher $(\mathrm{P}<0.05)$ than both E. aromatica $(74.40 .16 \pm 2.4)$ and H. suaveolens $(72.10 .58 \pm 2.8)$. Concentration of the secondary metabolites varied in the botanicals with $H$. suaveolens having higher flavonoids $(107.08 \mathrm{mg} / 100 \mathrm{~g})$, cardinolides $(46.06 \mathrm{mg} / 100 \mathrm{~g})$ and terpenoids $(3.17 \mathrm{mg} / 100 \mathrm{~g})$ while A. indica had higher saponins $(10.33 \mathrm{mg} / 100 \mathrm{~g})$ and phenols $(1938.48 \mathrm{mg} / 100 \mathrm{~g})$ while E. aromatica had comparatively higher alkaloids $(0.59 \%)$. The $\mathrm{LC}_{50}$ ranged from $3.61 \mathrm{mg} / \mathrm{kg}$ in $A$. indica, to $4.64 \mathrm{mg} / \mathrm{kg}$ in E. aromatica and $4.52 \mathrm{mg} / \mathrm{kg}$ in $H$. suaveolens. The ethanolic extracts of botanicals evaluated were more effective than the aqueous extracts and can serve as a substitute to the synthetic insecticides for the control of $P$. marginatus.
\end{abstract}

Keywords: Paracoccus marginatus, Botanicals, Carica papaya, Mealybug, Insecticide.

*Correspondence email:

okekesidney@yahoo.com 


\section{INTRODUCTION}

The papaya mealybug, Paracoccus marginatus Williams and Granara de Willink, is a small sized, polyphagous and highly invasive hemipteran pest that attacks several genera of host plants, including economically important tropical fruits, vegetables and ornamentals (Tanwar et al., 2010). It is believed to be native to Mexico and/or Central America although it has never gained status as a serious pest there, probably due to the presence of an endemic natural enemy complex (Miller et al., 1999). The papaya mealybug feeds on the sap of plants by inserting its stylets into the epidermis of the leaf, as well as into the fruit and stem. In doing so, it injects toxic substances into the leaves which cause chlorosis, plant stunting, leaf deformation, early leaf and fruit drop, a heavy build-up of honeydew and death of the plant. Symptoms start as bunchy top and end up in a candle stick appearance in young plants. Heavy infestations are capable of rendering fruits inedible due to the build-up of thick white wax (Walker et al., 2011).

The mealybug if not controlled, can cause multi-million dollar loss to numerous agricultural products (Walker et al., 2011). Since the first report of this mealybug in Africa in 2010, it has caused great concern in Ghana, where over 2000ha of papaya were under cultivation before it arrived. It was estimated that the pest destroyed over $80 \%$ of papaya farms, with a resulting yield loss of over $60 \%$ and a drastic reduction of the papaya orchards to less than $400 \%$. As a result, export earnings for the papaya industry significantly reduced and about 1700 persons in the sector lost their jobs (Georgen et al., 2011). The economic and ecological impacts of an imminent outbreak in Nigeria where, according to FAO (2010) 0ver $90 \%$ of papaya in West Africa is grown, are likely to be even more dramatic (Georgen et al., 2011). There are however reports that the pest has been a problem of papaya since 2012 in Ibadan, South-western Nigeria (Aduramigba, pers comm.). The use of synthetic insecticides such as organophosphates (malathion, chlorpyrifos and diazinone) or carbamates (dimethoate, carbaryl and acephate) to control $P$. marginatus, (Walker et al., 2011) is being deemphasized owing to the danger of possible outbreak of secondary pests normally kept in check by natural enemies (Omoloye, 2008; Prishanthini and Vinobaba, 2014). Due to the other problems such as human health hazards, undesirable side effects and environmental pollution caused by the continuous use of synthetic chemical pesticides, there is renewed interest in the application of botanical pesticides for crop protection (Prishanthini and Vinobaba, 2014).

Botanical pesticides are safe and biodegradable (Devlin and Zettel, 1999) and their use in crop protection is a practical sustainable alternative. They maintain biological diversity of predators and reduce environmental contamination and human health hazards (Grange and Ahmed, 1988).

Information on the control of $P$. marginatus with botanicals is scanty; hence the experiments reported here to evaluate the use of selected botanicals for the control of this pest.

\section{MATERIALS AND METHODS}

\section{Experimental Site}

All experiments were conducted at the Crop Research Garden and Entomology laboratory of the Department of Crop Protection and Environmental Biology (CPEB), University of Ibadan, Ibadan, Nigeria $\left(27 \pm 2^{\circ} \mathrm{C}, 70 \pm 5 \%\right.$ and 12:12 hour photoperiod). 


\section{Insect Culture}

Pawpaw fruits infested with $P$. marginatus were collected from the Biological Control Unit of National Horticultural Research Institute (NIHORT), Idi-Ishin, Jericho, Ibadan. They were kept at the Entomology research laboratory of the Department of CPEB where a larger culture was raised using pawpaw seedlings (8-12 weeks old).

\section{Source of planting materials}

Pawpaw seedlings of about 12 weeks were obtained from National Horticultural Research Institute (NIHORT), Idi-Ishin, Jericho, Ibadan.

\section{Collection of botanicals}

The botanicals (Hyptis suaveolens, Eugenia aromatica and Azadirachta indica) used for this experiment were all sourced locally within the premises of the University of Ibadan, Ibadan, Nigeria. Table 1 shows the source and description of the botanicals. The botanicals collected were washed with sterile distilled water until the dirt was completely removed and were shade dried, after which they were finely ground using Scanfrost Electric Blender (Model: SFKAB410) to obtain smaller particles of about $500 \mu \mathrm{m}$.

Table 1: Source and Description of Botanicals Evaluated as Protectants

\begin{tabular}{lllll}
\hline Botanical & Family & Common name & Part used & Source \\
\hline Eugenia aromatica & Myrtaceae & Clove & Fruit & Bode, Ib. \\
Hyptis suaveolens & Lamiaceae & Chan/Pignut & Leaves & Ajibode, Ib \\
Azadirachta indica & Meliaceae & Neem & Fruit & Within UI \\
\hline
\end{tabular}

Bode $\mathrm{Ib}=$ Bode market, Ibadan, Ajibode $\mathrm{Ib}=$ Ajibode area, Ibadan, UI,= University of Ibadan

\section{Preparation of ethanolic and aqueous extracts of Hyptis suaveolens, Eugenia aromatica and Azadirachta indica}

Ethanolic extraction was carried out using the method described by Lalone et al. (2007) and this involved using $500 \mathrm{~g}$ of ground shade dried $H$. suaveolens leaves, E. aromatica fruits and $A$. indica fruits which were transferred into the soxhlet extractor using analytical grade ethanol (99\%) as the solvent. The ethanol was removed by evaporating the extract in a rotary evaporator at $40-60^{\circ} \mathrm{C}$ until a semi-liquid oil extract was obtained. The oil extracts was further concentrated in a rotary evaporator under reduced pressure. The semi-liquid oil extracts was scooped into collection tubes and kept in a refrigerator for subsequent use.

Aqueous extraction was carried out following the method described by Okunlola et al. (2008), and this involved adding $200 \mathrm{~g}$ of ground shade dried $H$. suaveolens, $E$. aromatica and $A$. indica seeds into 1 litre of distilled water and the mixtures were allowed to stand for 24 hours after which they were filtered using a cloth filter to obtain a homogenous substance that was sprayed.

\section{Preliminary bioassay of oil extracts}

Preliminary bioassay was conducted in the Entomological Research Laboratory to determine the most effective concentration at which the oil extracts of the botanicals will be formulated for application. Different concentrations of the extracts; $3 \%, 5 \%$ and $10 \%$ were made. These concentrations; each added to $500 \mathrm{ml}$ of water, were sprayed using a hand sprayer after 2 days on 10 adult mealybugs carefully placed with a camel hair brush on 10 weeks old pawpaw seedlings. 
The setup was replicated four times. Effective concentration was determined using Probit analysis. Data on mortality of the mealybugs at $6 \mathrm{hrs}, 24 \mathrm{hrs}, 48 \mathrm{hrs}$ and $72 \mathrm{hrs}$ for each concentration was recorded. All data collected were subjected to arc-sine transformation to render them amenable to analysis of variance (ANOVA) at $\alpha .05$. After the preliminary experiment, the oil extracts were then formulated thus; $A$. indica $5 \%, H$. suaveolens $10 \%$ and E. aromatica $10 \%$ for the bioassay.

\section{Bioassay of ethanolic and aqueous extracts of Hyptis suaveolens, Eugenia aromatica and Azadirachta indica against $P$. marginatus}

Twelve (12) screen-cages (1.80x0.60x1.50m) each with $15 C$. papaya seedlings were set up at the Crop Garden of the Department of Crop Protection and Environmental Biology (CPEB), University of Ibadan. Ten (10) adult mealybugs were carefully placed on each plant using a fine camel hair brush and spraying of plants with the extracts commenced two days later. Each screen-cage served as a separate experimental unit and received a different treatment. The plant extracts were sprayed daily for three days. Synthetic insecticide (Cypermethrin ${ }^{\circledR}$ ) at recommended dosage of $100 \mathrm{ml} \mathrm{a.i} \mathrm{ha}{ }^{-1}$ was sprayed to serve as check. Mortality was corrected for using Schneider-Orelli's (1947) formula. All data collected were arc-sine transformed before they were analyzed using analysis of variance (ANOVA) at $\alpha .05$.

\section{Phytochemical Analysis of Plant Extracts}

Phytochemical screening for secondary compounds was performed using various methods to validate the presence and quantify the Phytoconstituents (Table 2). The botanicals were screened for saponins, alkaloids, terpenoids, phenols, flavonoids and cardinolides.

Table 2: Methods of Determination of Secondary Metabolites

\begin{tabular}{lll}
\hline Secondary metabolite & Method of determination & Remark \\
\hline Saponins & Frothing & Devmurari, 2010 \\
Alkaloids & Mayer & Chandrashekar et al., 2010 \\
Terpenenoids & Vanillin- $\mathrm{H}_{2} \mathrm{SO}_{4}$ & Doneva Šapceska et al., 2006 \\
Phenols & Folin-Ciocalteu & Chan et al., 2007 \\
Flavonoids & Sodium hydroxide & Ayoola,et al.,2008 \\
Cardinolides & Kedde & Manpreet, 2015 \\
\hline
\end{tabular}

\section{RESULTS}

\section{Preliminary Bioassay of Ethanolic Plant Extracts of $\boldsymbol{E}$. aromatica, $\boldsymbol{H}$. suaveolens and $\boldsymbol{A}$. indica against Adult $\boldsymbol{P}$. marginatus}

The effectiveness of the different plant extracts evaluated for contact toxicity against $P$. marginatus in the laboratory varied significantly with the different botanicals, doses and period of exposure (Table 3). Adult mortality of $P$. marginatus varied with period of exposure, ranging from 6.14$33.00 \%$ at 6hours to $35.21-90.00 \%$ after 72 hrs of exposure to the plant extracts.

The $10 \%$ concentration of $A$. indica had $33 \%$ mortality after $6 \mathrm{hrs}$ of exposure, $45 \%$ at $24 \mathrm{hrs}, 61 \%$ after $48 \mathrm{hrs}$ and $90 \%$ after $72 \mathrm{hrs}$ but this didn't differ significantly $(\mathrm{P}>0.05)$ from the $5 \%$ concentration which had $28.78 \%$ after $6 \mathrm{hrs}, 39.15 \%$ after $24 \mathrm{hrs}$, $70.07 \%$ at $48 \mathrm{hrs}$ and $84.15 \%$ at $72 \mathrm{hrs}$ of 
exposure. Both the $5 \%$ and the $10 \%$ concentrations differed significantly $(\mathrm{P}<0.05)$ from the $3 \%$ concentration which had the lowest mortality record with $12.28 \%$ after 6hrs, $21.15 \%$ after $24 \mathrm{hrs}, 26.07 \%$ at $48 \mathrm{hrs}$ and $35.21 \%$ at $72 \mathrm{hrs}$.

$10 \%$ E. aromatica concentration had $28.78 \%$ mortality at $6 \mathrm{hrs}, 41.15 \%$ at $24 \mathrm{hrs}$, $52.77 \%$ at $48 \mathrm{hrs}$ and $87.71 \%$ after $72 \mathrm{hrs}$ of exposure. This differed significantly $(\mathrm{P}<0.05)$ from the $5 \%$ concentration which had $21.15 \%$ mortality at $6 \mathrm{hrs}, 23.86 \%$ at $24 \mathrm{hrs}, 31.00 \%$ at $48 \mathrm{hrs}$ and $45.00 \%$ after $72 \mathrm{hrs}$. The least mortality was recorded on the $3 \%$ concentration which had $6.14 \%$ at
$6 \mathrm{hrs}, 18.43 \%$ at $24 \mathrm{hrs}, 23.85 \%$ at $48 \mathrm{hrs}$ and $39.14 \%$ after $72 \mathrm{hrs}$.

Lastly, $H$. suaveolens $10 \%$ concentration recorded $26.56 \%$ mortality after $6 \mathrm{hrs}$, $41.07 \%$ at $24 \mathrm{hrs}, 52.77 \%$ at $48 \mathrm{hrs}$ and $83.86 \%$ after $72 \mathrm{hrs}$ of exposure. This figures differed significantly $(\mathrm{P}<0.05)$ from the $5 \%$ concentration which had $15 \%$ after $6 \mathrm{hrs}$, $33 \%$ after $24 \mathrm{hrs}, 41.07 \%$ after $48 \mathrm{hrs}$ and $57.70 \%$ after 72 hours. The lowest mortality was recorded on the $3 \%$ concentration which was significantly lower than the $10 \%$ concentration across all time durations with $6.14 \%$ after $6 \mathrm{hrs}, 21.15 \%$ at $24 \mathrm{hrs}, 33 \%$ after $48 \mathrm{hrs}$ and finally $39.15 \%$ after $72 \mathrm{hrs}$ of exposure.

Table 3: Percentage Mortality Values for Three Concentrations (3, 5 and 10\%) of Ethanol Extracts of Three Plants Obtained in a Preliminary Bioassay on Adult P. marginatus (Mean $\pm \mathrm{SE}$ )

\begin{tabular}{lcllll}
\hline Treatment & $\begin{array}{c}\text { Concentration } \\
(\%)\end{array}$ & \multicolumn{4}{c}{ Mortality (\%) } \\
\cline { 3 - 6 } & 3 & $12.28 \pm 0.8 \mathrm{~cd}$ & $21.15 \pm 3.3 \mathrm{c}$ & $26.07 \pm 5.7 \mathrm{~cd}$ & $35.21 \pm 3.3 \mathrm{~cd}$ \\
Azadirachta & 5 & $28.78 \pm 3.3 \mathrm{ab}$ & $39.15 \pm 5.8 \mathrm{ab}$ & $70.07 \pm 8.8 \mathrm{a}$ & $84.15 \pm 6.7 \mathrm{a}$ \\
indica & 10 & $33.00 \pm 5.8 \mathrm{a}$ & $45.00 \pm 5.8 \mathrm{a}$ & $61.92 \pm 3.3 \mathrm{a}$ & $90.00 \pm 4.0 \mathrm{a}$ \\
& 3 & $6.14 \pm 0.3 \mathrm{~d}$ & $18.43 \pm 0.0 \mathrm{c}$ & $23.85 \pm 3.3 \mathrm{~cd}$ & $39.14 \pm 5.1 \mathrm{c}$ \\
Eugenia & 5 & $21.15 \pm 3.3 \mathrm{abc}$ & $23.86 \pm 3.3 \mathrm{c}$ & $31.00 \pm 3.3 \mathrm{~cd}$ & $45.00 \pm 5.8 \mathrm{bc}$ \\
aromatica & 10 & $28.78 \pm 3.3 \mathrm{ab}$ & $41.15 \pm 3.6 \mathrm{ab}$ & $52.77 \pm 3.3 \mathrm{ab}$ & $87.71 \pm 3.3 \mathrm{a}$ \\
& 3 & $6.14 \pm 0.3 \mathrm{~d}$ & $21.15 \pm 3.3 \mathrm{c}$ & $33.00 \pm 5.6 \mathrm{bcd}$ & $39.15 \pm 5.7 \mathrm{c}$ \\
Hyptis & 5 & $15.00 \pm 1.7 \mathrm{bcd}$ & $33.00 \pm 3.3 \mathrm{~b}$ & $41.07 \pm 5.1 \mathrm{bc}$ & $57.70 \pm 4.0 \mathrm{~b}$ \\
suaveolens & 10 & $26.56 \pm 2.1 \mathrm{abc}$ & $41.07 \pm 3.8 \mathrm{ab}$ & $52.77 \pm 3.3 \mathrm{ab}$ & $83.86 \mathrm{a} \pm 3.3 \mathrm{a}$ \\
& No Treatment & $0.00 \pm 0.0 \mathrm{~d}$ & $0.00 \pm 0.0 \mathrm{~d}$ & $5.29 \pm 1.0 \mathrm{~d}$ & $7.15 \pm 1.3 \mathrm{~d}$ \\
Control & & & & &
\end{tabular}

Mean \pm Standard error within a column followed by the same letter(s) are not significantly different at $\mathrm{p}<0.05$ using Duncan's Multiple Range Test (DMRT)

Percentage mortality for ethanolic extracts of three botanicals on adult $P$. marginatus is presented in Figure 1. All treatments evaluated differed significantly from the control across all time intervals (6hrs-72hrs). After $72 \mathrm{hrs}$, A. indica recorded the highest mortality $(87 \%)$. This was significantly higher than both E. aromatica (74\%) and $H$. suaveolens $(72 \%)$. There was no significant difference in the mortality values for E. aromatica and $H$. suaveolens after $72 \mathrm{hrs}$.

Percentage mortality of adult $P$. marginatus treated with aqueous extracts of three plants is presented in Figure 2. The aqueous extracts followed a similar trend to the ethanolic extract in that all treatments evaluated differed significantly from the control across all time intervals (6hrs-72hrs). After 72 hrs, highest mortality was recorded 
on A. indica $(54.2 \%)>$ E. aromatica $(48.6 \%)$ no significant differences among the three $>$ H. suaveolens (47.5). Although, there were extracts after $72 \mathrm{hrs}$.

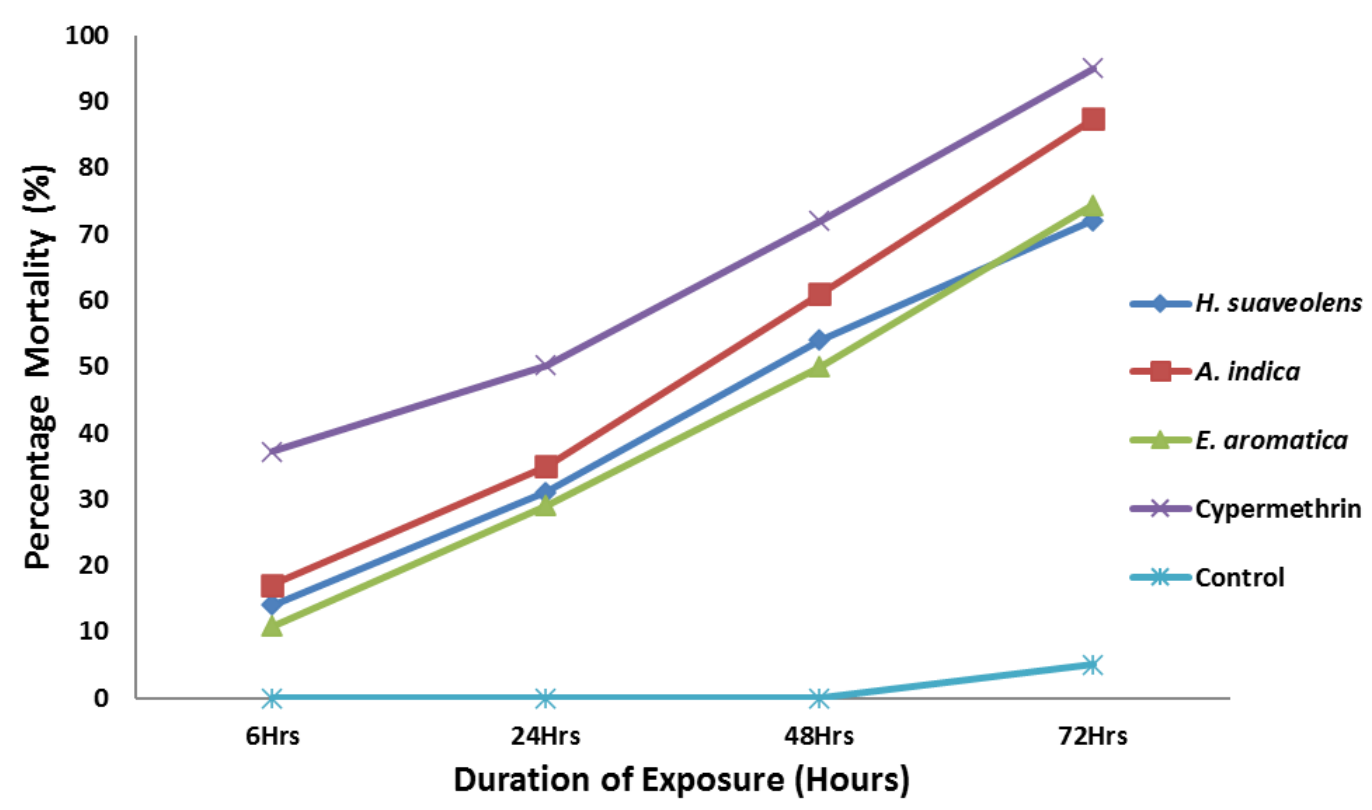

Figure 1: Percentage mortality of adult $P$. marginatus treated with ethanolic extracts of three plants

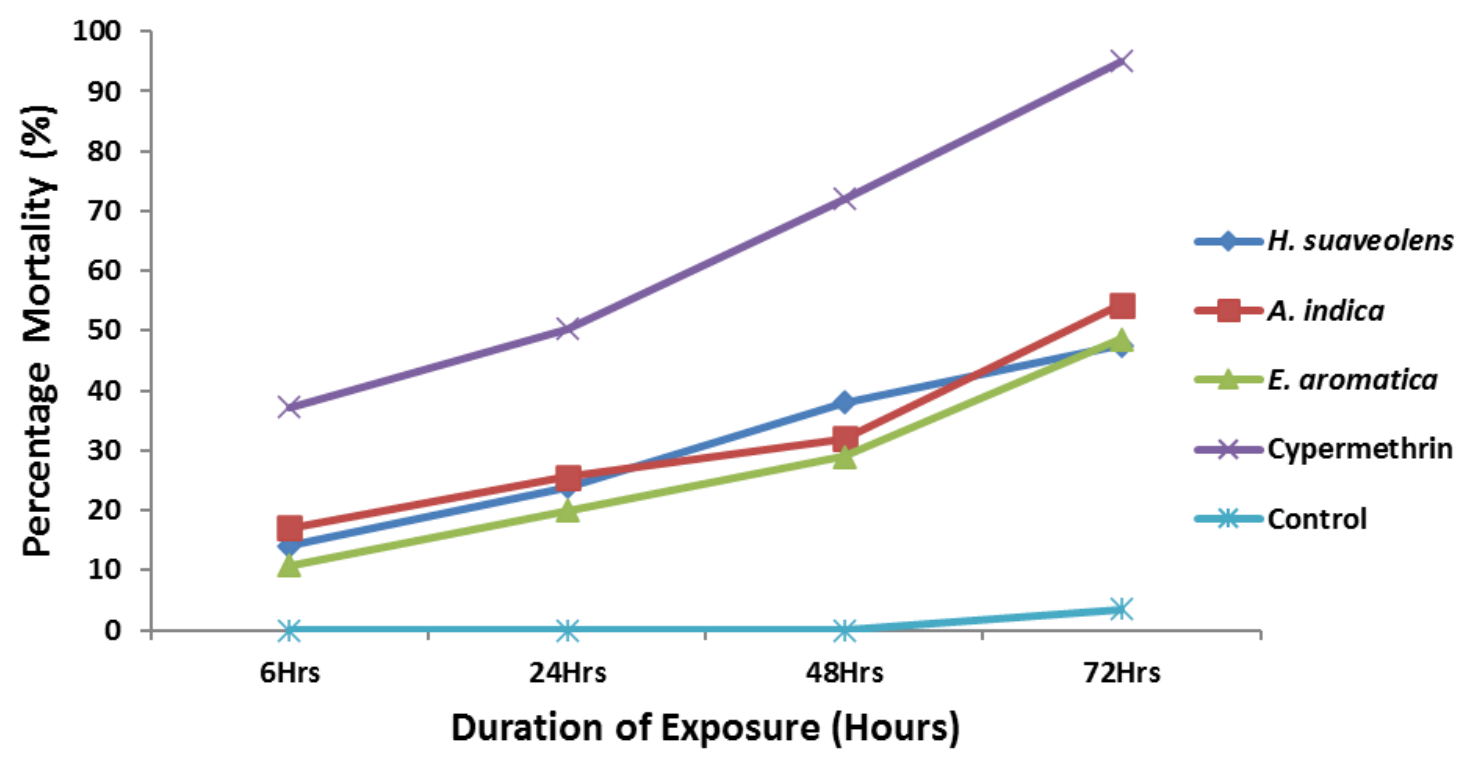

Figure 2: Percentage mortality of adult $P$. marginatus treated with aqueous extracts of three plants 
Concentration of Secondary Metabolites in E. aromatica, H. suaveolens, and A. indica

The amount of the secondary metabolites: flavonoids, saponins, alkaloids, terpenoids, cardinolides and phenols varied as presented in Table 4. Phenol was the most abundant of all secondary metabolites screened for in all the plant samples. It was found to be most abundant in $A$. indica $(1938.95 \mathrm{mg} / 100 \mathrm{~g})$, followed by $H$. suaveolens (1830.30 $\mathrm{mg} / 100 \mathrm{~g})$ then E. aromatica (1464.69 $\mathrm{mg} / 100 \mathrm{~g})$. Highest concentration of flavonoids was detected in $H$. suaveolens $(107.08 \mathrm{mg} / 100 \mathrm{~g})$, followed by $E$. aromatica $(94.53 \mathrm{mg} / 100 \mathrm{~g})$ and $A$. indica had the least concentration $(89.65 \mathrm{mg} / 100 \mathrm{~g})$. Cardinolides was found to be most abundant in $H$. suaveolens $(46.06 \mathrm{mg} / 100 \mathrm{~g})$, followed by $E$. aromatica $(30.68 \mathrm{mg} / 100 \mathrm{~g})$ then $A$. indica $(23.73 \mathrm{mg} / 100 \mathrm{~g})$. Highest concentration of saponins was detected in $A$. indica $(10.33 \mathrm{mg} / 100 \mathrm{~g})$, followed by $E$. aromatica $(8.63 \mathrm{mg} / 100 \mathrm{~g})$ then $H$. suaveolens $(6.47 \mathrm{mg} / 100 \mathrm{~g})$. Highest concentration of terpenoids was found in $H$. suaveolens $(3.17 \mathrm{mg} / 100 \mathrm{~g})$, followed by $A$. indica $(2.9$ $\mathrm{mg} / 100 \mathrm{~g})$ then $E$. aromatica $(2.18 \mathrm{mg} / 100 \mathrm{~g})$. Highest percentage of alkaloids was found in E. aromatica $(0.59 \%)$, followed by $A$. indica $(0.58 \%)$ then $H$. suaveolens $(0.17 \%)$.

$\mathrm{LC}_{50}$ values for the three botanicals evaluated as protectants are provided in Table 5. A. indica which proved to be the most potent had $\mathrm{LC}_{50}=3.61 \mathrm{mk} / \mathrm{kg}$ body weight of $P$. marginatus, followed by $H$. suaveolens $\left(\mathrm{LC}_{50}=4.52 \mathrm{mg} / \mathrm{kg}\right)$ then $E$. aromatica $\left(\mathrm{LC}_{50}=4.64 \mathrm{mg} / \mathrm{kg}\right)$.

Table 4: Phytochemical constituents of E. aromatica, H. suaveolens, and A. indica

\begin{tabular}{lccc}
\hline Metabolite composition & \multicolumn{3}{c}{ Plant Materials } \\
\cline { 2 - 4 } & E. aromatica & H. suaveolens & A. indica \\
\hline Flavonoids $(\mathrm{Mg} / 100 \mathrm{~g})$ & 94.53 & 107.08 & 89.65 \\
Saponins $(\mathrm{Mg} / 100 \mathrm{~g})$ & 8.63 & 6.47 & 10.33 \\
Cardinolides $(\mathrm{Mg} / 100 \mathrm{~g})$ & 30.68 & 46.06 & 23.73 \\
Terpenoids $(\mathrm{Mg} / 100 \mathrm{~g})$ & 2.18 & 3.17 & 2.9 \\
Total Phenols $(\mathrm{Mg} / 100 \mathrm{~g})$ & 1464.69 & 1830.36 & 1938.48 \\
Alkaloids $(\%)$ & 0.59 & 0.17 & 0.58 \\
\hline
\end{tabular}

Table 5: $\mathbf{L C}_{50}$ Values for Three botanicals Determined Using Probit Analysis

\begin{tabular}{lc}
\hline Botanicals & $\mathbf{L C}_{\mathbf{5 0}}(\mathbf{m g} / \mathbf{k g})$ \\
\hline Azadirachta indica & 3.61 \\
Eugenia aromatica & 4.64 \\
Hyptis suaveolens & 4.52 \\
\hline
\end{tabular}

\section{DISCUSSION}

Hyptis suaveolens, E. aromatica and A. indica extracts (ethanolic and aqueous) caused mortality of adult $P$. marginatus, though their effectiveness was dependent on the duration of exposure as mortality increased with increase in duration of exposure. The preliminary results indicated that after $72 \mathrm{hrs}$ of exposure among all treatments, different concentration caused different mortality levels, indicating that the effectiveness of the extracts evaluated were dose dependent.

Hyptis suaveolens was able to cause mortality of adult $P$. marginatus. This is in line with the report of Musa et al. (2009) where Trogoderma granarium was successfully controlled in stored groundnut using $H$. suaveolens and the rates of 
treatment were observed as an important factor affecting its toxic effect. In addition, the leaf extract of $H$. suaveolens have also been reported to reduce the population of Spodoptera litura and Aphis craccivora on groundnut (Ignacimuthu and Jayaraj, 2003). Similarly, in this study, application of $H$. suaveolens leaf extracts reduced population of $P$. marginatus with an increase in treatment rates.

Extracts of E. aromatica was effective as contact spray against $P$. marginatus. This agrees with the findings of Olotuah (2014) who reported the successful control of stored products insects; Sitophillus zeamais, Callosobrochus maculatus, Sitophillus oryzae and Tribolium castaneum with ethanolic extract of essential oil of $E$. aromatica and that it was also dependent on the levels of concentration of oil administered. Also, that E. aromatica is known to have pungent smell. Adedire and Lajide (2001); Longe (2004) also reported that $E$ aromatica has significant contact and fumigant action against C. maculatus.

Extracts of $A$. indica caused mortality of adult $P$. marginatus. This is in accordance with the reports of other researchers; Badshah et al. (2015) and Prishanthini and Vinobaba (2014) reported the successful control of the cotton mealybug Phenacoccus solenopsis using neem seed extract in Pakistan and Sri Lanka respectively. Saikia et al. (2000) reported that leaf (10 to 50\%) and seed kernel (5\%) extracts of neem caused significant mortality of the bean aphid Aphis craccivora. Kalyanasundaram and Das (1985) reported that plants in the families Meliaceae and Lamiaceae possess insecticidal activities which include ovicidal, larvicidal, antifeedant and repellence.

Reynolds, (1987) reported that essential oils and their constituents affect biochemical processes, which specifically disrupt the endocrinologic balance of insects. They may be neurotoxic or may act as insect growth regulators, disrupting the normal process of morphogenesis

The phytochemical analysis revealed the presence of important secondary metabolites, many of which have been reported to possess insecticidal properties. Secondary metabolites interfere with certain vital components of the cellular signaling system and interfere with vital enzymes, involved in signaling in the nervous system and block metabolic pathways (Wink, 2000). Terpenoids and alkaloids are reported as candidates for insecticidal compounds that could be an effective alternative for insect pest management. Alkaloids have been known to possess insecticidal properties (Secoy and Smith, 1983). Terpenes causes disturbance in the nervous system leading to paralysis and mortality.

\section{CONCLUSION}

Results obtained from the bioassay demonstrated the good potential of these plants as insecticides. Thus, these plant products can be utilized for preparing botanical insecticides which is a good alternative to conventional synthetic insecti-cides as they are safe, economical and readily available. Therefore, $A$. indica at $5 \%$ concentration, $H$. suaveolens at $10 \%$ concen-tration and $E$. aromatic at $10 \%$ concentration are recommended for the control of $P$. marginatus and their formulation and production on a larger scale could also be considered beyond laboratory evaluation.

\section{ACKNOWLEDGEMENTS}

The authors thank the National Horticultural Research Institute, Ibadan, Nigeria (NIHORT) for providing the initial culture of mealybugs used for the research and also for fully funding this research through a collaborative project between NIHORT and 
International Institute of Tropical Agriculture (IITA) with Grant from the Swiss Agency for Development and Cooperation.

\section{REFERENCES}

Adedire, C. O. and Lajide, L. (2001). Efficacy of powders of some tropical plants in the control of the pulse beetle, Callosobruchus maculatus (F.) (Coleoptera: Bruchidae). Appl. Trop. Agric. 6: 11-15.

Ayoola, G. A., Folawewo, A. D., Adesegun, S. A., Abioro O. O., Adeppoju, A. A. and Coker, H. A. B. (2008). Phytochemical screening and Antioxidant Activities of Some Plants of Apocynaceae from South West Nigeria.Afr. J Plt Sc. 2(9)124-128.

Badshah, H., Ullah, F Farid, A., Calatayud, P. A, Crickmore, N., (2015). Toxicity of Neem seed Azadirachta indica Juss (Meliaceae) different solvents extracts against cotton mealybug Phenacoccus solenopsis Tinsley (Sternorrhyncha: Pseudococcidae) under Laboratory conditions. Journal of Entomology and Zoology Studies 3(4): 45-49

Chan, E.W. C., Lim, Y.Y., Chew, Y.L., (2007). Antioxidant activity of Camellia sinensis leaves and tea from lowland plantation in Malaysia. Journal of Food Chemist; 102: 1214-1222.

Chandrashekar, K., Santanu, S. and Prasanna, K. (2010). Phytochemical studies of aerial parts of the plant Leucasla vandulaefolia. Der. Pharma. Chemica., 2 (5):434-43

Delvin, J. F. and Zettel, T. (1999). Ecoagriculture: Initiatives in Eastern and Southern Africa. Weaver Press, Harare Journal of Plant Molecular Biology., 6(2): 150-152.

Devmurari, V. P., (2010). Phytochemical screening study and antibacterial evaluation of Symplocosra cemosa Roxb. App. Sci. Res.2(1):354-359.

Doneva-Šapceska, D., Dimitrovski, A., Bojadžiev, T., Milanov, G. and Vojnovski, B. (2006). Free and potentially volatile monoterpenes in grape varieties from the republic of Macedonia. Maced
Journal of Chemist Chem. Engr; 25(1): 5156.

Georgen, G., Tamo, M., Bokonon-Ganta, A. H., Neuenschwander, P., (2011). Papaya mealybug: a New Invading Pest in West Africa, Biocontrol News and Information www.researchgate.net/publication/2359223 80

Grange, N. and Ahmed, S. (1988). Handbook of Plants with Pest Control Properties. John Wiley and Sons, New York. 7(5): 75-78

Ignacimuthu S, and Jayaraj S. (2003). Ecofriendly approaches for sustainable insect pest management. Current Science 84(10): 1292-1293.

Kalyanasundaram, M. and Das, P. K. (1985). Larvicidal and synergistic activity of plant extracts for mosquito control. Indian Journal of Medical Research; 82:19-23.

LaLone CA, Hammer DD, Wu L, Bae J, Leyva N, Liu Y, Solco AD, Kraus GA, Murphy PA, Wurtele ES, Kim OK, Seo K, Widrlechner MP, Birt DF (2007). Echinacea species and alkamides inhibit prostaglandin $\mathrm{E}(2)$ production in RAW264.7 mouse macrophage cells. Journal of Agric Food Chem. 55 (18): 7314-22.

Longe, O. O. (2004). Fumigant toxicity of some botanical powders to eggs and larvae of Callosobruchus maculatus (F) (Coleoptera: Bruchidae). M. Agric. Tech. Thesis, The Federal University of Technology, Akure, Nigeria.

Manpreet, K., (2015). Classification and Chemical Tests for Cardiac Glycoside. Your article library.Retrieved on May 12, 2015 from http://www.yourarticlelibrary.com/biology/ glycoside/cardiac-glycoside-classificationand-chemical-tests-for-cardiacglycosides/49746

Miller, D. R, Williams, D. J and Hamon, A. B. (1999). Notes on a new mealybug (Hemiptera: Coccoidea: Pseudococcidae) pest in Florida and the Caribbean: the papaya mealybug, Paracoccus marginatus Williams and Granara de Willink. Insecta Mundi 13: 179-181. 
Musa, A.K. Dike, M.C and. Onu, I. (2009). Evaluation of Nitta (Hyptis suaveolens Poit.) Seed and Leaf Extracts and Seed Powder for the Control of Trogoderma granarium Everts (Coleoptera: Dermestidae) in Stored Groundnut. American-Eurasian Journal of Agronomy 2 (3): 176-179.

Okunlola, A. I., Ofuya T. I and Aladesanwa R. D. (2008). Efficacy of Plant Extracts on Major Insect Pests of Selected Leaf Vegetables in Southwestern Nigeria. Agricultural Journal 3 (3): 181 -184, 2008 ISSN: 1816-9155.

Olotuah O. F. (2014). Bio-efficacy of oil extract of Eugenia aromatica in the control of storage insect pests. International Journal of Geology, Agriculture and Environmental Sciences Volume -2 Issue-4 August

Omoloye, A. A. (2008). Fundamentals of Insect Pest Management. Corporate Publishers Lagos, p. 211.

Prishanthini, M. and Vinobaba, M. (2014). Efficacy of some selected botanical extracts against the Cotton mealybug Phenacoccus solenopsis (Tinsley) (Hemiptera: Pseudococcidae) International Journal of Scientific and Research Publications, Volume -2 Issue-4 ISSN 2250-3153

Raffa, K.F., Priester, T.M., (1985). Synergists as research tools and control agents in agriculture. Journal of Agricultural Entomology 2, 27-45.
Reynolds, S.E. (1987). The cuticle, growth and moulting in insects: the essential background to the action of acylurea insecticides. Pesticide Science 20, 131-146.

Saikia P, Das D, Saikia L (2000). Evaluation of botanicals and fish oil formulation against bean aphid, Aphis craccivora Koch. J. Agric. Sci. Soc. North-East, India, 13: 7980.

Schneider-Orelli O. (1947). Entomologisches Parktikum-Einfurung in die land-un forstwirtschafliche insektenkunde. Sauerlander and Co., Aarau, Germany.

Secoy, D.M., Smith, A.E. (1983). Use of plants in control of agricultural and domestic pests. Economic Botany 37, 28-57.

Tanwar, R.K, Jeyakumar, P. and Vennila S. (2010). Papaya mealybug and its management strategies, Technical Bulletin 22, National Centre for Integrated Pest Management, New Delhi

Walker, A., Hoy, M, and Meyerdirk, D. (2011). Papaya mealybug, Paracoccus marginatus Williams and Granara de Willink (Insecta: Hemiptera: Pseudococcidae). Florida Cooperative Extension Service, Institute of Food and agricultural Sciences, University of Florida, Gainesville, FL.

Wink, M., (2000). Interference of alkaloids with neuroreceptors and ion channels. Studies in Natural Products Chemistry 21, 3-12.
NJE Vol. 36: 54-63, 2020

Nigerian Journal of Entomology

Published by the Entomological Soc. of Nig.

www.esnjournal.com.ng

DOI.10.36108/NJE/0202/63.01.60

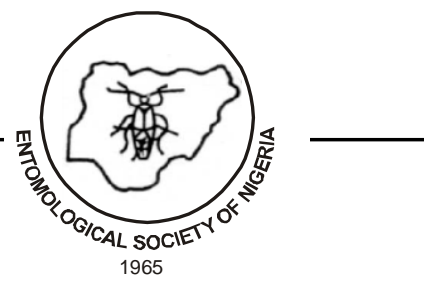

